\title{
Application of Participatory Design to Facilitate Social Innovations Ideas with Charity Organizations
}

\author{
Olena Saienko \\ School of Design and Informatics \\ Abertay University \\ Dundee, Scotland \\ 1905278@abertay.uad.ac.uk
}

\begin{abstract}
Participatory design (PD) method is widely used in design for social innovations. Current research on design for social innovations discuss variety of design processes for different stakeholders, however, there is a lack of attention to co-design process with charity organisations. This study investigates how to support social innovations creation through co-design with charity organisations to produce solutions that will address local community's needs. To generate innovative ideas, study will apply creative workshops, as a PD tool, involving charities and volunteers in Dundee, Scotland. This research will aim to contribute to the PD literature by illustrating co-design methodology for social innovation idea generation for the charities, as an actor of social changes.
\end{abstract}

Social Innovation, Participatory design, Co-design, Charity organisations, Local innovations.

\section{INTRODUCTION}

Over the past decades, Participatory design (PD) research has developed from the workspace context in Scandinavian countries to technical and social field of studies (Spinuzzi, 2005; Sanders, 2008). Shifting focus from the user-centered approach to co-design and co-creation practices, $\mathrm{PD}$ has been moving from designing material goods to designing for "people's purposes" (Sanders, 2008). Following this tendency PD design practice and research have started to address complex social issues, conceptualizing in design for social innovation. As a research field, social innovations topic is gaining popularity and has been already studied as a multidisciplinary phenomenon from a sociological, economic, political point of view for several decades (Giddens 2009). Mulgan (2009) has raised important questions on the benefits and opportunities of utilizing design methods to contribute social innovation. Further, Manzini (2015) has defined the concept of social innovations as a new way to achieve socially acknowledgeable goals by the creative restructuring of existing resources. One of the fundamental books on design for social innovations is "Design, when everybody designs" by Manzini, outlines practical and theoretical aspects of design for social innovations, defining the role of participatory design and designer in the creation of social innovations.

The trending and actuality of this research are supported by successful activities of current government-based projects oriented on social innovations development through design as well as a growing number of Living labs around the world. Among vivid and big scale projects there are:

- Innovation Union by EU

- Horizon 2020 that put SI as one of the priorities fields.

- The Organization for Economic Cooperation and Development to support public sector innovation (OECD).

- Design Council's Public Services in UK (Design Council).

- Such researcher groups as POLIMI DESIS Lab (DESIS Network) have successfully implementing co-design practices on the big number of international and local projects.

Local and regional development has become one of the fields where social innovation has become the main research subject (Moulaert at al., 2005). Thus, participatory design, as a tool that allows involving local stakeholders, can play a significant and irreplaceable role to address particular needs 
of local communities. Supported by Mulga (2009), Manzini (2014), Murray (2010) participatory design redefine the role of a designer bringing to the front stakeholders (non-designers) as important actors and contributors to design process for social changes. Within social innovations design research field with and for third sector organisations more attention is paid to communities (Björgvinsson, 2012; Hillgren, 2011) and social enterprises (Selloni, 2017; Konsti-Laakso, 2016) as an actor of social changes, however, there is a lack of studies on co-design with charities, outlining design process specifically for this actor.

To fulfil this gap my research will investigate how participatory design with charities and related actors will support social innovations creation on the local level. Thus, the main research question is: "How to support social innovation creation through a co-design process with charity organizations to produce solutions that will address community needs? The aim is to apply a participatory design methodology to facilitate the creation of communityfocused social innovation concepts. Current research will outline PD case study with charity organisations as an actor for the local social changes, focusing on design process. The characteristics of charities I aim to work with are relatively small, locally based, with limited resources. The research will supplement PD design methodology offering a tool kit for co-design with charities.

\section{REFERENCES}

Björgvinsson, E., Ehn, P. and Hillgren, P.A., 2012. Agonistic participatory design: working with marginalised social movements. CoDesign, 8(23), pp.127-144.

Design Council. Retrieved from: https://www.designcouncil.org.uk/

DESIS Network. Retrieved from: https://www.desis.polimi.it/about/
European commission. Retrieved from https://ec.europa.eu/

Giddens, A. 2009. The politics of climate change. Cambridge: Polity Press

Hillgren, P.A., Seravalli, A. and Emilson, A., 2011. Prototyping and infrastructuring in design for social innovation. CoDesign, 7(3-4), pp.169-183.

Konsti-Laakso, S., Koskela, V., Martikainen, S.J., Melkas, H. and Mellanen, L., 2016. Participatory design of a social enterprise for rehabilitees. Work, 55(1), pp.145-153.

Manzini, E. 2014. "Making Things Happen: Social Innovation and Design." Design Issues 30 (1): 57-66. doi:10.1162/DESI_a_00248.

Manzini, E. 2015. Design, when everybody designs: An introduction to design for social innovation. Cambridge, Massachusetts; London, England: The MIT Press.

Moulaert, F., Martinelli, F., Swyngedouw, E., \& González, S. 2005. Towards alternative model(s) of local innovation. Urban Studies, 42(11), 19691990. doi:10.1080/00420980500279893

Mulgan, G. 2009. Social Innovation Exchange Conference. London, December.

Murray, R., Caulier-Grice, J. and Mulgan, G. 2010. The Open Book of Social Innovation. London, UK: Young Foundation and Nesta

OECD. Retrieved from: https://www.oecd.org/

Spinuzzi, C., 2005. The methodology of participatory design. Technical communication, 52(2), pp.163-174.

Sanders, E.B.N. and Stappers, P.J., 2008. Cocreation and the new landscapes of design. Codesign, 4(1), pp.5-18.

Selloni, D. and Corubolo, M., 2017. Design for social enterprises: How design thinking can support social innovation within social enterprises. The Design Journal, 20(6), pp.775794. 